\title{
In the Middle: Career Pathways of Midlevel Community College Leaders
}

\author{
Regina L. Garza Mitchell \\ Texas State Technical College - Harlingen, regina.garza-mitchell@harlingen.tstc.edu \\ Pamela L. Eddy \\ College of William \& Mary, pamela.eddy@wm.edu
}

Follow this and additional works at: https://scholarworks.wm.edu/articles

Part of the Community College Leadership Commons

\section{Recommended Citation}

Garza Mitchell, Regina L. and Eddy, Pamela L., "In the Middle: Career Pathways of Midlevel Community College Leaders" (2008). Articles. 58.

https://scholarworks.wm.edu/articles/58

This Article is brought to you for free and open access by W\&M ScholarWorks. It has been accepted for inclusion in Articles by an authorized administrator of W\&M ScholarWorks. For more information, please contact scholarworks@wm.edu. 
In the Middle:

A Gendered View of Career Pathways of Mid-Level Community College Leaders

\author{
Regina L. Garza Mitchell \\ Pamela L. Eddy \\ Central Michigan University
}


Community colleges are experiencing an unprecedented turnover in administration, particularly at the senior levels (Katsinas \& Kempener, 2005; Shults, 2001). The crisis in community college leadership is heightened by the pending retirement of upwards of $70 \%$ of community college presidents within the next ten years (Schults, 2001). Indeed, over $45 \%$ of sitting presidents are 61 or older (American Council on Education [ACE], 2007), demanding increased attention to the career pathways within community colleges. This changing of the guard provides a prime opportunity for more women to move into senior ranks.

Career opportunities within higher education have expanded over time for women, though they still comprise a disproportionately small number of community college leaders. In 1986 only $8 \%$ of community college presidents were women compared with $29 \%$ in 2006 (ACE, 2007). Even though this increase in representation is laudable, the ascent of women to the presidential office slowed in the past five years, growing by a mere $2 \%$. This decrease may represent a glass ceiling. The inequity in numbers is striking, especially since $56 \%$ of all undergraduate students and 59\% of community college students are women (NCES, 2004). The imbalance is even more apparent in women of color, who made up a mere $7 \%$ of public community college presidents (Harvey \& Anderson, 2005).

Several studies have been conducted on pathways to the presidency (e.g., Birnbaum \& Umbach, 1991; McKenney \& Cejda, 2001; Vaughan, 1990; Walton \& McDade, 2001) and the literature on leadership in general tends to focus on the senior levels. The mid-level range of leaders is apt to be overlooked (Amey, VanDerLinden, \& Brown, 2002) as are the career paths leading up to them. To better understand pathways to formal positions of leadership, it is necessary to understand the individual steps they have taken, as experience influences the mental maps that guide leadership behavior (Eddy, 2004; Senge, 1990). Previous studies have indicated 
a leadership pathway beginning with a faculty position and ending with a presidency (Birnbaum \& Umbach, 1991; Schults, 2001; Vaughan, 1990). For example, community college faculty members tend to function in leadership roles as department chair and/or members of faculty senate and/or union, which often lead to upper-administrative positions (Schults, 2001).

As bureaucratic institutions, community colleges reward and rely on an organizational hierarchy (Birnbaum, 1992). Thus, the route to the upper level positions, including the presidency, is most often marked by a series of promotions up the career ladder. Indeed, $60 \%$ of current community college presidents came to their current positions either from a previous presidency (26\%) or from the Chief Academic Officer position (34\%) (ACE, 2007).

Amey, VanDerLinden, and Brown (2002) studied mid-level leadership in community colleges, focusing on career paths, mentoring, and types of professional development. They found that $22 \%$ of the current community college presidents came from within the institution, $56 \%$ of the participants had a mentor, and the career trajectory of presidents followed the traditional academic pathway of promotion through the hierarchy. They concluded that the path to the presidency was changing with more routes becoming open to this top leadership position. However, the authors determined that work remained in generating wider candidate pools for these senior level positions, and in particular, providing entry level administrators the breadth of experiences to acquire the requisite skills necessary for future promotions. In a follow-up survey, VanDerLinden (2003) asked if participants had been promoted or moved in position since the undertaking of the initial survey in 2000. Participants identified two key barriers to advancement: the lack of opportunities within their current institutions and unwillingness to relocate for a new position. This finding runs contrary to research that indicated four-year administrators are willing to move for promotions (Sagaria, 1988). 
Boggs (1988) researched the characteristics of sitting presidents and found that requisite skills included an advanced degree, a willingness to move, active roles in the community, and the ability to speak before large audiences. As noted earlier, career stops in the dean's office and the chief academic officer's position often occurred on the way to the president's office. Wolverton and Gonzales (2000) reported that women and minorities are still underrepresented in deanships. More telling was their finding that the deans in this study did not follow a set career trajectory nor did they view their position as a natural stepping stone to the provost position. Rather, onequarter of the deans surveyed indicated they had plans to return to the faculty. In a study of the career paths of women chief academic officers, McKenney (2000) found that gender influenced the amount of time in each position and that women were moving faster through their career paths relative to their male peers. Yet, this increased pace of movement has not significantly influenced the number of women obtaining a presidency. Clearly, something happens for women on the path to the presidency. Understanding more about the lived experiences of mid-career administrators can help provide support for upper level positions and identify pathways that lead to higher-level positions.

Community colleges are perceived as being more open to women (Townsend, 2006), however they remain gendered organizations. Existing structures and processes create different experiences and expectations along gender lines despite claims of neutrality (Acker, 1990; Eddy \& Cox, in press). Community colleges are hierarchical bureaucracies and as such are based on traditional structures which favor men. "Since men in organizations take their behavior and perspectives to represent the human, organizational structures and processes are theorized as gender neutral" (Acker, p. 142). The dominant male perspective represents the ideals for work and the attitude of employees toward work. Williams (2000) used the term "ideal worker" to 
reference expected preferences in employees, again based on male ideals that may not fit a number of men or women. The ideal worker is expected to be on the job in excess of 40 hours a week, with an unspoken understanding that their personal and family responsibilities are met by someone else in the home (a wife figure). Women in leadership positions are expected to meet ideal worker expectations in addition to responsibilities they may have on the second shift (Hochschild, 1989). These gendered expectations may be a barrier for women who desire to advance but also have responsibilities in caring for elderly relatives or young children.

Experiences of leaders in the community college pipeline remain unknown. Why do some mid-level leaders not advance to higher positional levels of leadership within colleges and universities? Are mid-level leaders opting out due to barriers or lack of support? The key questions at the heart of this research study are: what are the career trajectories of mid-level administrators and what is the influence of gender/gendered leadership on careers?

\section{Methods}

This research was taken from a larger study on the career trajectories of mid-level academic leaders. Data for this research were culled from a medium, rural community college. All academic mid-level leaders were invited to participate. For purposes of this study, mid-level leaders were defined as directors or deans of an academic unit and department chairs. Since this college does not employ chairs, lead faculty members were asked to participate. Three directors/deans and six lead faculty contributed to this study. Semi-structured interviews were conducted, combining Ray’s (1994) “clue and cue” process (p. 129) with Holstein and Gubrium's (1995) active interviewing approach. This less structured form of interviewing allowed for dialogue to occur rather than mere question and answer. 
A feminist phenomenological approach was used to uncover themes that captured the essence of individuals' experiences as perceived by the individuals themselves (Bogdan \& Taylor, 1975). Phenomenology seeks to present a phenomenon - in this case a career trajectory from participants' perspectives, and attempts to describe rather than explain a phenomenon (Creswell, 1997; Lester, 1999; Ray, 1994). Interview data were coded using NVivo to determine overall themes. Peer review of findings aided in confirmation of patterns evolving from the data.

\section{Findings}

Findings from this research revealed several themes. First, mid-level leaders at the community college are still firmly rooted in the classroom. All faculty members in chair-level positions and most director/deans at this rural college were involved in teaching. Second, participants had not planned to progress to their current positions, and only one expressed desire to move upward to a more advanced position. There were high levels of satisfaction with current positions and requirements. Finally, there was no formal structure in place to mentor future leaders or to provide development for current leaders on issues of administration or leadership. Leading from their current positions drew upon the self-identified participatory leadership style of the participants.

\section{Career Pathways}

Participants had varied career pathways previous to working at the college. The two female deans had been full-time faculty prior to moving into the dean positions, and the male director was a student services administrator and taught as an adjunct before being asked to assume the director position. The director/deans had each been in three different career fields prior to academic administration (see Table 1). Similarly, the lead faculty lines demonstrated a 
mixture of backgrounds with the majority of faculty discovering their love of teaching during graduate school (see Table 2).

Table 1

Career Pathways of Director/Deans

\begin{tabular}{|l|l|l|l|l|l|}
\hline & Step 1 & Step 2 & Step 3 & Step 4 & Step 5 \\
\hline $\begin{array}{l}\text { Dean A } \\
\text { female) }\end{array}$ & $\begin{array}{l}\text { Practicing Nurse/ } \\
\text { Administrator }\end{array}$ & Adjunct Faculty & $\begin{array}{l}\text { Full-time } \\
\text { Faculty/ } \\
\text { Coordinator }\end{array}$ & Dean & \\
\hline $\begin{array}{l}\text { Dean B } \\
\text { female) }\end{array}$ & Food service & Paralegal & $\begin{array}{l}\text { Full-time } \\
\text { Faculty }\end{array}$ & Dean & \\
\hline $\begin{array}{l}\text { Director C } \\
\text { (male) }\end{array}$ & K-12 Teacher & $\begin{array}{l}\text { Student } \\
\text { Services } \\
\text { Administrator }\end{array}$ & $\begin{array}{l}\text { Small-Business } \\
\text { Owner/ Adjunct } \\
\text { Faculty }\end{array}$ & Registrar & Director \\
\hline
\end{tabular}

Table 2

\begin{tabular}{|c|c|c|c|c|c|}
\hline $\begin{array}{l}\text { Career } \\
\text { Pathways } \\
\text { of Lead } \\
\text { Faculty } \\
\text { Members }\end{array}$ & Step 1 & Step 2 & Step 3 & Step 4 & Step 5 \\
\hline $\begin{array}{l}\text { Faculty A } \\
\text { (female) }\end{array}$ & $\begin{array}{l}\text { Grad School/ } \\
\text { Grad Assistant }\end{array}$ & $\begin{array}{l}\text { Consulting work/ } \\
\text { Adjunct Faculty }\end{array}$ & $\begin{array}{l}\text { Full-time } \\
\text { Faculty / Lead } \\
\text { Faculty }\end{array}$ & & \\
\hline $\begin{array}{l}\text { Faculty B } \\
\text { (female) }\end{array}$ & Grad School & $\begin{array}{l}\text { Full-time } \\
\text { Faculty/ Lead } \\
\text { Faculty }\end{array}$ & & & \\
\hline $\begin{array}{l}\text { Faculty C } \\
\text { (female) }\end{array}$ & Grad School & $\begin{array}{l}\text { Full-time Faculty } \\
\text { (Research } \\
\text { Institution) }\end{array}$ & $\begin{array}{l}\text { Full-time } \\
\text { Faculty/ Lead } \\
\text { Faculty }\end{array}$ & & \\
\hline $\begin{array}{l}\text { Faculty D } \\
\text { (male) }\end{array}$ & $\begin{array}{l}\text { Grad School / } \\
\text { Grad Assistant }\end{array}$ & Full-time Faculty & \begin{tabular}{|l} 
Full-time \\
Faculty/ Lead \\
Faculty
\end{tabular} & & \\
\hline $\begin{array}{l}\text { Faculty E } \\
\text { (male) }\end{array}$ & $\begin{array}{l}\text { Grad school / } \\
\text { Grad Assistant }\end{array}$ & Adjunct Faculty & $\begin{array}{l}\text { Full-time } \\
\text { Faculty }\end{array}$ & $\begin{array}{l}\text { Full-time } \\
\text { Faculty / } \\
\text { Lead } \\
\text { Faculty }\end{array}$ & \\
\hline $\begin{array}{l}\text { Faculty F } \\
\text { (female) }\end{array}$ & Business & $\begin{array}{l}\text { Small-Business } \\
\text { Owner/Operator }\end{array}$ & Grad School & $\begin{array}{l}\text { College } \\
\text { Staff }\end{array}$ & $\begin{array}{l}\text { Full-time } \\
\text { Faculty/ Lead } \\
\text { Faculty }\end{array}$ \\
\hline
\end{tabular}

\footnotetext{
${ }^{1}$ Director $\mathrm{C}$ was promoted to a deanship subsequent to this interview.
} 
The career pathways of participants were varied and circuitous. Most had not planned on a community college administrative role, and they rarely planned to work in a community college at the start of their career. One faculty member initially worked at a research institution but intentionally sought out a community college for her next teaching position. She noted, I decided I didn't want to write grants anymore, I was tired of publishing and perishing, and I have 30 some-odd high-level publications, and I just got tired of that competition for national grants. I then decided I just wanted to teach. So, I looked around and I thought a community college, a community college would be nice. And this is the only one that would consider me because I was so overqualified.

Another faculty discovered her aptitude for teaching while developing training sessions for employees in the business sector.

I started structuring training programs. I think that's when I started realizing that, gosh, I sort of have a knack for this and I like to do it. And you know, dealing with objectives and then rolling out the curriculum and that kind of thing.

Key areas became evident regarding career pathways. First, central to movement along the career pathway was being tapped for administrative positions, even if faculty did not initially seek out administrative responsibilities. This lack of intentionality was defined as being an Accidental Leader. Strong ties to classroom teaching also kept participants from seeking further advancement when it meant relinquishing direct time with students. Accidental Leaders

The fact that the participants were located in smaller departments often meant they were the only full-time faculty members and by default the department leader. One faculty leader noted, "We don't have a formal department, I mean I am the sociology department full-time." 
Faculty members wore multiple hats, moving in and out of positions of leadership on various committees and projects. They were asked to assume leadership positions without formally moving up in the college. The ability to weave in and out of administration allowed for a means of testing out leadership and influencing decision-making.

Individuals were able to lead, without moving up, through short term assignments, creating their departments' curriculum, and building new programs. The ability to do more without a formal title provided opportunity through faculty leadership. Participants were able to serve as leaders and mentors to part-time faculty and newer full time faculty. The participants found value in their contributions and often had turned down multiple offers for advancement. One lead faculty stated, "I've been asked to be department head, I've been asked to apply for deans, whatever. But I said, 'No, why would you want to take one of your best teaching faculty out of the classroom?"”

Involvement in union leadership also provided a means for faculty to develop leadership skills. In these positions faculty were able to interact with college administration and influence outcomes. One academic dean noted that her career at the community college began subsequent to retiring to the area with her husband after a long nursing career. She moved from her faculty position to the dean's job when the college president asked her if she would fill that role.

Our dean left, and I really wasn't interested. I liked teaching. I liked having the summers off. ..and then the upper management came to me and said, 'Would you consider stepping in as interim?' And I said, 'I really don't want this. 'I'm getting to the point where I'm looking at the retirement picture, and they're looking at making me work harder. So I tell them 'Okay.' I'm taking it as an interim for six months while they looked around. And, gee, I kind of liked it. 
None of the participants in the study, including all three deans, sought their positions of leadership but rather ended up in these positions by "accident" or by being asked to step into a position. One academic director noted that he had never applied for a position in the college, save one, that he did not get. He also pointed out that he had been asked to move into each of the positions that moved him up the ladder. "I'm just minding my own business and somebody asks me to take on a responsibility, and this is a nice ego boost. And I - boy, you can't say no." Mentors and particular college administrators often served as the fulcrum for suggesting a move to administration. Typically, the participants described scenarios in which they were approached or placed in administrative positions versus seeking them out. One dean noted, "Things have just kind of walked in front of me," and she added, "When opportunities knock, you have to be willing to flex, if you're not, you're going to get trampled." Rooted in Teaching

It was apparent that all participants in this study were rooted in teaching. All participants acknowledged their love of teaching and working with students. One lead faculty came into her current position after working as a full-time faculty member at a research institution. She reflected on her reason for moving to the community college sector:

I think the ultimate career goal was I wanted to be an outstanding professor in my area, because there aren't a lot of specialists in my area. And I think teaching is very important to me, but I also like research. And so I was known for very outstanding research programs. But, personally, I preferred the teaching. I liked the teaching more in this stage. That blended to my background earlier in life. So, and right now, no, I think I'm doing exactly what I need to be doing, right. And so this is my goal. I do not want to be an administrator at all. No aspirations that way. 
Contentment with current position was the main reason lead faculty gave for not wanting to move up the administrative hierarchy. As another lead faculty member noted,

Maybe it's one of the ways - reasons - I've always avoided just becoming an administrator. I think teaching is an avocation. It's not a job, you know. So it, I mean, it's what I do. I read, I think, I talk, I teach, and am taught by my students at the same time. To me it's what attracted me to this in the first place and it keeps you vital. It keeps you thinking and moving and those kinds of things in a way.

In addition to a love of teaching, all of the lead faculty were satisfied with their teaching positions and also with the degree of administration that they had. The ability to play a more active administrative role without going into full-time administration was due to the size and culture of the school. One faculty member stated that, "I guess the leadership position that I currently hold is primarily due to the fact that as a small community college, many of our departments are held down by one full-time instructor." Another faculty concurred:

I've been in a situation where I've been able to do what I like best, which is to teach and I'm not interested in not teaching, you know, I've never really been interested in being strictly an administrator, but still do things that in a four-year school or even in a larger community college would have been reserved as administrative work because these kinds of institutions don't have the layers of bureaucracy and redundant positions, professional positions that allow people to specialize in the little sort of niche work that you see in a large research institution. So for me, it's been a great fit because I've gotten to be whatever I wanted.

Links to the classroom started for most of our participants through adjunct opportunities, either in addition to a full time professional job or during graduate school. A research university 
is located in the same vicinity as the community college and served as the initial training ground for several of our participants. One such university alumnus commented, "When I was a graduate assistant at [the university] for three semesters, I was given one class completely.....If I hadn't done the graduate assistantship, I never would have known that teaching is what I want to do."

\section{Gendered Institutions}

The term "gendered organization" reflects the idea that organizations are affected by workers' gender, race, class, and sexuality (Briton, 2000). Thus, “gender is a foundational element of organizational structure and work life" (Briton, p. 419). Though the community college in the study was referred to as "close-knit" and having a family-like atmosphere, participants in the study acknowledged that ideals and processes in the college were based on antiquated notions of gender. At least one participant referred to the college as an "old boy's network," despite the fact that the college employed more women in senior leadership positions.

\section{The Ideal Worker}

Norms based on the ideal worker (Williams, 2000) provided little incentive for advancement with those seeking a different type of life balance. All participants took ideal worker standards for granted, as evidenced by the comments of one faculty member.

I've just been trained this way, and I operate. I don't know of any other way to operate...People here can't believe the amount of work I can do. That this is normal. This is where I came from. This is what I'm used to.

The existing administrative structure and hierarchical expectations gave our participants little incentive to move into administrative positions that were higher up the organizational ladder. The lack of financial incentives and additional time requirements of working in the summer months were mentioned by many of the participants. A promotion would mean a pay cut 
and require working year round. Further, the institution in this study had no formal leadership development or succession planning. The president of the college was one of its founding faculty members and was set to retire after a 40-year career at the institution. Individuals interested in moving ahead in leadership had to develop their skills on their own. Most participants expressed satisfaction with their current positions, and only two indicated a desire to seek advancement.

The majority of the participants were long-serving college employees. The organizational structure of the community college was based on a clear hierarchy with polar perceptions of faculty versus administration, conforming to the historically male norms that serve as the measure of leadership within community colleges (Amey \& Twombly, 1992). An ideal worker ideology (Williams, 2000) was inherent throughout the institution. One lead faculty member pointed out, "The rule at [College], informally, is that if you come here and do your job really well, you'll get a pay check. If you come here and do your job really well and then do other things, you'll get a promotion. You cannot get promoted by doing your job.” Both faculty and director/deans expected long hours of work. Faculty who had not moved into director or deanlevel positions often listed the inflexible hours and expectation of a different type of work as deterrents to advancing to higher positions. However, faculty mentioned that they probably worked as many, if not more, hours than the deans, but their love of the job made that acceptable. "Once I started teaching, I determined early on, I did not want to be an administrator. They work 40 hours a week on somebody else's schedule. I work more than 40 hours a week during the year, but on my schedule."

One female lead faculty member talked about her decision not to advance to a higher position. 
The job demands, the time, could possibly influence women from either going into that field or not going into the field. When I was division chair, I realized that I'm a completer of projects type person and in the classroom, you've got a definite start, stop, semester by semester. And a leadership, an administrative position, you get three projects and maybe you get time to finish one, and then you're given two more, and then you can finish one more and then you have all of the meetings... and the time involved. There are so many time requirements for those administrator roles. And especially if you have a family, if you want to have a personal life, even if you want to keep physically fit, you know, to fit in exercise along with those different time requirements, it's really, really tough. And there are always more meetings. There's always a new project. Which is invigorating, but yet, if you're a completer it's also a demotivator at times as well.

The expectations of the job demanded time which took away from any other type of personal pursuits. This type of job structure is rooted in expectations that someone else tended to responsibilities of the home. For those in the study who did not have a partner working on home issues, it meant working a second shift after work.

\section{Gendered Roles}

Both male and female participants in the study noted issues of gender at the institution. Gendered organizations (Acker, 1990) advantage the male norm regarding the distribution of power. Though there were more females in mid- and upper-level positions at this college, one male faculty noted, "I think it [community college] is more female friendly, but I bet you'll find it's run by more masculine rules." Women who were appointed or moved into a role indicated they had to act differently and were treated differently because of their sex. One dean noted having to bite her tongue because of antiquated beliefs about gender. A lead faculty concurred. 
There still seems to be a tendency that the strong male personality is considered a go getter. A strong female personality is considered a . . I don't think it has to be that way. But as a male seems to say, 'This is the way it's going to be.' There's a different reaction if a female saying, 'This is the way it's going to be.' Because you're dealing with so many males versus females within that level, and if we don't really aspire to conflict-laden positions...

As noted earlier, the college had a high number of females in upper-level administrative leadership positions, but academic leadership positions were dominated by males. In fact, one lead faculty member was told that she was hired because she was a female. "It was a big factor, because the males that were interviewing me said that they wanted a female with a Ph.D. so that it would be good role model for [College] students. Yeah, so I was the first Ph.D. here.” A female dean commented on her perceptions of gender in the administrative ranks. She stated,

I remember coming to the first meeting [leadership cabinet] in my new role as a dean, and the guys were all joking around and having fun, and I said, "Okay guys. I put my pants on the same way you do. I have boobs, you have balls. So let's get over it and let's play the game!" They kind of looked at me and the HR person gasped. But you know, they needed to know that just because I was a woman didn't mean that I wasn't part of the team.

A lead faculty member described how men seemed to have titles at the college, whereas women were treated as administrative secretaries and asked to relay messages and information. Gendered expectations played a large role in mid-level positions at the site college. 


\section{Career Role Models}

The "accidental" nature of the route to their current positions illustrated a lack of intentional planning to enter administration. In much the same way that the participants came to the community college via circuitous routes, so, too, did they arrive in their current positions of leadership. When asked about mentoring, responses represented two distinct experiences. Some of the participants indicated they did not have a mentor, whereas others quite specifically listed one or more mentors. Those without formally identified mentors were not without guidance, however. Participants identified upper level administrators as key role models. For instance, when asked if she had a mentor, one of the lead faculty responded, "Not anything that was formal or official. In my life and my career, I just kind of try to pick out people who are different aspects of things that I might want to learn from them or model from them.” Merely watching how other leaders operated within the college and in handling their administrative functions provided a template of how to function as an administrator.

The lead faculty who came to the college from a research university commented on the role of mentors in her discipline:

I had a very strong mentor in veterinary medicine. She was outstanding. There weren't many women back when I went through. She was an excellent teacher, an excellent researcher, and that's where I picked up a lot of my habits from her, being very well organized....I do think mentors make a huge difference in terms of females in science. Likewise, the dean of allied health noted how she modeled her democratic style of leadership after a former supervisor, "She was very democratic. We had, as a staff, we had a big part in the decision-making and she formed a lot of liaison-type committees to work through all of the problems. She was such a powerful influence on the changes that occurred." Mentors served to 
highlight participants' potential for advancement. One dean noted that when she was an adjunct faculty member, “After my first year when I did my first evaluation my dean said, 'Someday you're going to sit in my chair.' I laughed at her and said, 'Oh, yeah, right!'” This early prediction proved to be true.

One lead faculty discussed the mentoring relations and the obligations required of both parties. She stated,

I realized that the mentoring relationship really has accountability on both ends. I think it holds the person being mentored accountable because you get as much as you put into it. You can't just say, "Oh, I have a mentor, " and treat it as though it's the mentor's responsibility to teach you. You really have to be proactive and say, "I'm lucky and fortunate to have this person in my life." I'm going to learn everything that I can possibly learn and really spend time thinking about goals for the relations.

For some, mentoring started with fellow faculty in acclimating to teaching life at the community college. Mentoring occurred throughout the career path, with several of the participants being tapped for advancement through being identified by a campus insider.

Formally identified mentors and those whose behavior is modeled served as guides for the participants in our study. Even for those who said they did not have mentoring noted how they benefited from observation of others. One director stated, "I have not had obvious mentoring, a formal mentoring system, no, never had but as observation of former supervisors. Putting myself under someone's wing, as opposed to them bringing me under their wing is what I've done." Sources of administrative observation were the administrators at the college. Upper level administrators were watched in how they led meetings, how they dealt with people, and how they solved problems. 
The need to begin mentoring of new faculty was noted by lead faculty. One lead faculty stated, "I really think there is value in rotating [faculty leadership opportunities] through the faculty and mentoring new faculty that we have to take these positions." Another lead faculty concurred, stating “Those of us who've been here a while look around and say, 'We've got to train some leaders because we're going to be gone in a few years."' The lack of a formal mentoring program or leadership development within the college was viewed as a trend to change. All of the mid-level leaders in the college had come from the faculty ranks, underscoring the importance of faculty mentoring.

\section{Discussion/Conclusion}

Administrators in this study came to their positions through a variety of routes-none of which involved a traditional trajectory of faculty role to chair to dean. The complexity of the career paths evidenced here highlights a need to think differently about how community colleges recruit leaders. In order to create a larger pool for future administrative openings, close ties within the community and in business is needed. The lead faculty and deans who joined the community college more recently came with a bundle of life experiences outside of the two-year culture. It is important to determine ways to infuse the historical context and culture of the community college to these newcomers.

The lack of a formal mentoring program or leadership development plan meant that the individuals placed into new administrative roles were often left to figure out things for themselves. Several of the lead faculty started their careers as adjunct faculty when they were graduate students. The period of socialization for faculty work, and ultimately for administration, began during this time period. Austin (2002) reviewed the need for socialization during the graduate years for faculty work, but with the assumption that this faculty career would occur in 
the same type of institution, namely a research university. In the case of community college faculty coming to teach from graduate school, not only may they not be aware of the demands of the position, but they do not have the contextual understanding of work within the two-year sector. Mentoring at the community college could ease this transition and plant the seed for newcomers of the potential benefits of pursuing an administrative career. VanDerLinden (2004) concluded that women in leadership at community colleges were in a position to shape the organizational culture to create an inclusive environment for women administrators. Given the critical role of being "tapped" to seek advancement, who is recognized and encouraged for advancement opens up the pipeline.

The availability of formal training programs by the American Association of Community Colleges and The League of Innovation were not tapped as resources by participants or their college. Expense of the programs and the happenstance landing in administrative ranks meant that the participants were not specifically seeking training for leadership roles. Some states, such as Iowa, have devised their own leadership academies to take a proactive approaches to preparing leadership for the future (Amey, 2006). These learning opportunities can plant the seeds for individuals to think of seeking upper level positions. Another example of a partnership to develop community college leadership is the MidSouth Partnership for Rural Community Colleges (MSP), a regionally specific “grow your own” leadership development program that helps community college leaders build sustainable rural communities (Clark \& Davis, 2007). These types of programs may appeal to those who are place bound or have no desire to move in order to achieve the goal of advancement.

The small size of the site college meant that participants could meet their personal desires to lead and influence from where they were. Thus, they saw no need to advance to more formal 
leadership positions since they could accomplish what they felt needed from where they were. Feeding this lack of motivation to advance along the career ladder were the participants' strong ties to the classroom. Faculty members who teach at a community college usually choose to do so because these institutions are teaching-focused and support education to improve the lives of students who might not otherwise have a chance. Participants in this study did not perceive any additional benefits to higher level positions and in some cases, there were actual detriments such as pay cuts or the loss of summers off. This lack of desire to advance may ultimately exasperate the pending leadership crisis in community colleges. Upper-level leadership must appear more attractive as a job destination in order to attract more and different leaders.

Though leading from the middle was rewarding for the participants, this behavior does not get at the root of changing the existing gendered structures based on the ideal worker nor does it change the gender roles currently in place. For women, the preponderance of the "old boy" network often meant their foray into the next organizational level was charged. The slowing down of women entering the community college presidential ranks —only a $2 \%$ increase in the last five years (ACE, 2007) — underscores that the gendered nature of the community college may be a limiting factor for advancement. The ideal worker (Williams, 2000) is disconnected from life outside of work. Acker (1990) referred to this as the disembodied worker, which represents a male with home support for personal needs. One new dean who noted the “antiquated ideas about gender" added, "I segregate my work from my personal life as much as I possible can. I had high speed Internet access at home, and I got rid of it. I have no Internet access at home so that when I am at home, I am not at work. It's a very conscious decision on my part." This individual choice to set boundaries was one reaction to the expectations of the ideal worker. 
Underscoring the issues of work-life balance were the requirements of administrative work. One lead faculty stated,

My foray into "administrative work" has largely been an attempt to do things, control my own area, my territory.... and the other is how over the last 25 years or so administration in higher education has become its own professional end in itself. I really like the older model of the marriage of instructional, administrative, teaching, and administrative roles that faculty should play.

Lead faculty, in particular, noted the control they have in the classroom and over their time. Becoming an administrator meant having less say over how to spend time and operating within the confines of the organizational hierarchy. Rethinking work roles and the organizational structure may mean working with a flatter organizational structure with a team approach (Bensimon \& Neumann, 1993) or web of inclusion (Helgeson, 1995).

Colleges should consider what is needed to make leadership more attractive. Establishment of grow-your-own programs may eliminate a barrier outlined by VanDerLinden (2004) regarding the lack of desire to move. Moreover, identification of potential leaders allows for more intentional mentoring and skill-building rather than relying on individuals becoming accidental leaders who are underprepared for the challenges of the job. Intentionality in development would allow a wider array of employees the chance to test drive administration and cultivate individuals who may not have first considered a leadership position. The need to come to upper level positions with a variety of institutional experiences underscores the necessity of internal development support. This tactic can be particularly useful for those less often in the corner office — namely women and leaders of color. 
In summary, this research found that mid-level administrators had high levels of job satisfaction which contributed to their lack of desire to consider more advance leveled positions. Participants were able to lead from where they were in their mid-level positions and exercise influence on decision-making at the college. The desire to stay connected to the classroom also made upper level positions less attractive. The community college in this research operated as a gendered institution, which valued ideal workers based on male norms within the existing hierarchy. As the leadership void becomes more pressing at the top, colleges must consider how to best use their own resources to grow and sustain future leaders. Institutions need to rethink what it means to be a senior level administrator and redesign positions that may prove to be more attractive to those currently in the middle. The ability to still be tied to students, to allow for jobsharing, and to obtain life-balance may ultimately create a larger pipeline to the top. 


\section{References}

Acker, J. (1990). Hierarchies, jobs, bodies: A theory of gendered organizations. Gender and Society, 4(2), 139-158.

American Association of Community Colleges. (2007). Facts 2007. Washington, D.C.: AACC.

Amey, M. J. (2005). Conceptualizing leading as learning. Community College Journal of Research and Practice, 29(9-10), 689-704.

Amey, M. J. (2006). Breaking tradition: New community college leadership programs meet $21^{\text {st }}$ century needs. Washington, DC: American Association of Community Colleges.

Amey, M. J., \& Twombly, S. B. (1992). Revisioning leadership in community colleges. The Review of Higher Education, 15(2), 125-150.

Amey, M. J., VanDerLinden, K., \& Brown, D. F. (2002). Perspectives on community college leadership: Twenty years in the making. Community College Journal of Research and Practice, 26(7), 573-589.

Austin, A. E. (2002). Preparing the next generation of faculty: Graduate school as socialization to the academic career. Journal of Higher Education, 73, 94-122.

Bass, B. M., \& Avolio, B. J. (Eds.). (1994). Improving organizational effectiveness through transformational leadership. Thousand Oaks, CA: Sage Publication.

Bennis, W. (1987). The four competencies of leadership. School Library Media Quarterly, 15(4), 196-199.

Bensimon, E. M., \& Neumann, A. (1993). Redesigning collegiate leadership: Teams and teamwork in higher education. Baltimore, MD: The Johns Hopkins University Press. 
Bensimon, E. M., Neumann, A., \& Birnbaum, R. (1989). Making sense of administrative leadership: The "L" word in higher education. ASHE-ERIC Higher Education Report No. 1 ED 316074 MF-01. Washington, DC: The George Washington University.

Birnbaum, R., \& Umbach, P.D. (2001). Scholar, steward, spanner, stranger: The four career paths of college presidents. The Review of Higher Education, 24(3), pp.203-217.

Bogdan, R., \& Taylor, S. J. (1975). Introduction to qualitative research methods: A phenomenological approach to the social sciences. New York: John Wiley.

Bolman, L., \& Deal, T. (2003). Reframing organizations: Artistry, choice, and leadership. San Francisco: Jossey-Bass.

Briton, D. M. (2000). The epistemology of the gendered organization. Gender and Society, $14(3), 418-434$.

Burns, J. M. (1978). Leadership. New York: Harper \& Row.

Corrigan, M. E. (2002). The American college president: 2002 edition. Washington, DC: American Council on Education Center for Policy Analysis.

Creswell, J. W. (1997). Qualitative inquiry and research design: Choosing among 5 traditions. Thousand Oaks, CA: Sage.

Davis, J. (2003). Learning to lead. Westport, CT: American Council on Education, Praeger Publishers.

Eddy, P. L. (2004). The impact of presidential cognition on institutional change. Community College Enterprise, 10(1), 63-77.

Eddy, P. L., \& Cox, E. (2008). Gendered leadership: An organizational perspective. In J. Lester (Ed.), Gendered Perspectives on Community Colleges. New Directions for Community Colleges (pp. 69-79). San Francisco: Jossey-Bass. 
Glass Ceiling Commission. (1995). Good for business: Making full use of the nation's human capital. Washington, DC: Glass Ceiling Commission.

Green, M. (1997). No time for heroes. Trusteeship, 5(2), 6-11.

Harvey, W. B., \& Anderson, E. L. (2005). Minorities in higher education 2003-2004: Twentyfirst annual status report. Washington, DC: American Council on Education.

Helgesen, S. (1995). The web of inclusion: A new architecture for building great organizations. New York: Currency/Doubleday.

Hochschild, A. R. (1989). The second shift: Working parents and the revolution at home. New York: Viking.

Katsinas, S. G., \& Kempner, K. (2005). Strengthening the capacity to lead in the community college: The role of university-based leadership programs. Lubbock, TX: National Council of Instructional Administrators.

Kezar, A. J. (2000). Pluralistic leadership: Incorporating diverse voices. The Journal of Higher Education, 71(6), 722-743.

Kezar, A. J. (2002 July/August). Expanding notions of leadership to capture pluralistic voices: Positionality theory in practice. Journal of College Student Development, 43(4), 558-579.

Lester, S. (1999). An introduction to phenomenological research. Retrieved October 11, 2005, from http://www.devmts.demon.co.uk/resmethy.htm

McKenney, C. B. (2000). Women chief academic officers of public community colleges: Career paths and mobility factors. (Doctoral dissertation, Texas Tech University, 2000). 
McKenney, C. B., \& Cejda, B. D. (2001). The Career Path and Profile of Women Chief Academic Officers in Public Community Colleges. Advancing Women in Leadership, $9(1)$.

National Center for Education Statistics. (2004). Digest of Education Statistics, 2004. Washington DC: US Department of Education.

Nidiffer, J. (2001). New leadership for a new century: Women's contribution to leadership in higher education. In J. Nidiffer and C.T. Bashaw (Eds.), Women Administrators in Higher Education: Historical and Contemporary Perspectives, pp. 101-131. Albany, NY: State University of New York Press.

MacGregor, D. M. (1960). The human side of enterprise. New York: McGraw-Hill Companies. Peterson, M. (1997). Using contextual planning to transform institutions. In M. Peterson, D. Dill, L. A. Mets, \& Associates (Eds.), Planning and Management for a Changing Environment, 127-157. San Francisco: Jossey-Bass Publishers.

Ray, M. A. (1994). The richness of phenomenology: Philosophic, theoretic, and methodological concerns. In J. M. Morse (Ed.), Critical issues in qualitative research methods (pp. 117133). Thousand Oaks, CA: Sage.

Senge, P. M. (1990). The fifth discipline: The art and practice of the learning organization. New York: Doubleday.

Shults, C. (2001). The Critical impact of impending retirements on community college leadership. Leadership Series Research Brief No. 1. Washington, D.C.: American Association of Community Colleges, 2001.

Twombly, S. B. (1995). Gendered images of community college leadership: What messages they send. New Directions for Community Colleges, 89, 67-77. 
VanDerLinden, K. E. (2004). Gender differences in the preparation and promotion of community college administrators. Community College Review, 31(4), 1-24.

Vaughan, G. (1990). Pathway to the presidency: Community college deans of instruction. Washington, D.C.: The Community College Press.

Walton, K. D., \& McDade, S.A. (2001). At the top of the faculty: Women as chief academic officers. In J. Nidiffer \& C.T. Bashaw (Eds.), Women Administrators in Higher Education: Historical and Contemporary Perspectives. (pp.85-100). Albany, NY: State University of New York Press.

Williams, J. (2000). Unbending gender: Why family and work conflict and what to do about it. New York: Oxford Press. 